\title{
Trends in sexual orientation in Brazil
}

\author{
Hudson W. de Carvalho \\ Universidade Federal de Pelotas, RS, Brasil \\ Simone Conte Dall'Agnol \\ Diogo Rizzato Lara \\ Pontificia Universidade Católica do Rio Grande do Sul, RS, Brasil
}

\begin{abstract}
The current study aimed to evaluate the prevalence of sexual identities in Brazil across age and sex based on five categories (heterosexuals, mostly heterosexuals, bisexual, mostly homosexuals, and homosexuals) and to assess homoerotic ideation and behavior in heterosexuals. The data were collected using self-report questionnaires in a research website. Data from 41,873 participants were collected and analyzed. From total sample, $78.2 \%$ of males and $89.8 \%$ of females self-declared to be heterosexuals. The most prevalent minorities were homosexuals (4.6\%) and mostly heterosexuals (4.1\%). Same-sex ideation and behavior among heterosexuals was frequent and gender differences were robust. Orientation identities other than substantial heterosexuals seem to be more prevalent in the younger generations.
\end{abstract}

Keywords: sexual minorities; sexual orientation identity; Internet research methods; gays, lesbians and bisexuals.

\section{Tendências da orientação sexual no Brasil}

Resumo

Avaliou-se a prevalência de identidades sexuais em homens e mulheres de diferentes gerações com base em cinco categorias (heterossexuais, predominantemente heterossexuais, bissexuais, predominantemente homossexuais e homossexuais) e aferiu-se a ideação e comportamentos homoeróticos em heterossexuais. A coletada de dados foi realizada por meio de questionários de autorrelato disponibilizados em um sitio de pesquisa na Internet. Dados de 41.873 Brasileiros foram colhidos e analisados. Do total, $78.2 \%$ dos homens e $89.8 \%$ das mulheres se declaram heterossexuais, a minoria sexual mais prevalente foi a de homossexuais (4.6\%) e de predominantemente heterossexuais (4.1\%). Ideação e comportamentos homoeróticos em heterossexuais foram frequentes e diferenças entre homens e mulheres foram robustas. Não heterossexualidades foram mais prevalentes em gerações mais jovens.

Palavras-chave: minorias sexuais; orientação sexual; métodos de pesquisa pela internet; gays, lésbicas e bissexuais.

\section{Tendencias de orientación sexual en Brasil}

\section{Resumen}

Se evaluó la prevalencia de las identidades sexuales en hombres y mujeres de diferentes generaciones sobre la base de las cinco categorías (heterosexuales, predominantemente heterosexuales, bisexuales, predominantemente homosexuales y homosexuales) y la ideación y conductas homoeróticas fueran evaluadas en heterosexuales. Los datos fueron recolectados a través de cuestionarios de autorrelato en un sitio de pesquisa en la Internet. Se recogieron y analizaron datos de 41.873 brasileños. Del total, el 78,2\% de hombres y $89,8 \%$ de las mujeres dicen que son heterosexuales, la minoría sexual más prevalente era homosexual (4,6\%) y predominantemente heterosexual (4,1\%). Ideación y conductas homoeróticas en heterosexuales fueran comunes y las diferencias entre hombres y mujeres fueran robustas. Identidades non heterosexuales fueron más prevalentes en las generaciones más jóvenes.

Palabras clave: minorías sexuales; orientación sexual; la investigación sobre los métodos de Internet; homosexuales, lesbianas y bisexuales. 


\section{Introduction}

The concept of sexual orientation is classically defined as sexual impulses of a person towards those of other sex, same sex or both. This understanding led common sense and some researchers to merge sexual orientation identity with sexual attraction and produce and reaffirm a taxonomy based on three independent categories: heterosexuals, bisexuals, and homosexual (Sell, Wells, \& Wypij, 1995; Abdo, 2004; 2010). However, this three-category taxonomy has outgrown its utility: since Kinsey's reports on the sexuality of the American men (Kinsey, Pomeroy, \& Martin, 1948) and women (Kinsey, Pomeroy, Martin, \& Gebhard, 1953), it became quite clear that one's sexual orientation does not predict perfectly one's sexual ideation, behavior and affection and that the identity variability can not be reduced to three categories alone. Furthermore, studies that focus on more recent generations (like teenagers and young adults) have shown patterns of sexual and affectional variability that cannot be accounted for these three categories alone and, most importantly, shows that sexual orientation is only partially stable. For example, individuals who declare themselves as "pure" hetero or homosexuals may display erotic fantasies, engage in sexual activity or even develop romantic relationships with both: same-sex or other-sex partners (Diamond, 2003). Also, hetero or homoerotic fantasies and experiences may occur, with or without affective components at any time of the life cicle (Kaplan, 1984; McCabe, Brewster, \& Tillman et al., 2011).

Kinsey, Pomeroy and Martin (1948) proposed taxonomy in which sexual orientation identity was classified on the basis of seven categories: exclusively heterosexual, predominantly heterosexual and incidentally homosexual), predominantly heterosexual and more than incidentally homosexual, equally heterosexual and homosexual, predominantly heterosexual and more than incidentally homosexual, predominantly heterosexual and incidentally homosexual, and homosexual. Kinsey et al. (1948) reported that approximately $4 \%$ of men are exclusively homosexual throughout their lives, while $10 \%$ are exclusively homosexual for at least three years between the ages of 16-55. Additionally, more than one out of three experience sexual interaction with another man until the onset of puberty (Kinsey et al., 1948), 37\% of post-pubertal males and $20 \%$ of post-pubertal females have already had some sort of sexual experience with someone of the same sex and that $13 \%$ and $17 \%$, respectively, had more sexual experience with someone of the same sex than with someone of the other sex (Kinsey et al., 1948; Kinsey et al., 1953).
The data described by Kinsey reports and his co-workers (Kinsey et al., 1948; Kinsey et al., 1953), although innovative and of unequivocal historical and political relevance, had several methodological limitations (Maslow \& Sakoda, 1952; Voeller, 1990). The dataset on which the analyses were performed showed a disproportionate number of prison inmates (many of whom were sex offenders), and African Americans (although interviewed) were not included. Also, college students and people recruited via homosexual-friendly magazines or organizations were over-sampled. Also, the distinction of the statistical and supplementary data is not totally clear, mixing interview based information with participants personal journal or daily records. Finally, all participants volunteered, which may have generated a bias in which respondents were more likely to be sexually adventurous. Despite these methodological limitations, such evidence shows that there is a clear gradation between bisexuality and the extremes of pure hetero/homosexuality.

Cross-cultural data on the prevalence of sexual behavior based on mainstream interview or paperand-pencil surveys shows that gays and lesbians that exclusively have same-sex behavior characterized no more than $1 \%$ of the adult population (Sell, Wells, \& Wypij, 1995; Black, Gates, Sanders, \& Taylor, 2000). Nevertheless, if the definition is broadened by sexual contact with both sexes and/or some degree of samesex attraction, the proportion of gays and lesbians raises to approximately one fifth of the population (Saving-Williams \& Ream, 2007). In Brazil, surveys that focus on prevalence of sexual identities or behavior based on population samples are quite rare, the only published report on the subject shows that 3.9\% and $4.7 \%$ of men and $1.9 \%$ and $1.2 \%$ of women declared to be homosexual or bisexual, respectively (Abdo, 2004). Nevertheless, this study used the classical triad heterosexual/bisexual/homosexual to evaluate participants' sexual orientation identity.

Two recent systematic reviews (Saving-Williams \& Vrangalova, 2013; 2014) argued for the legitimacy of a group composed of mostly heterosexuals, a group located between exclusively heterosexuals and substantial bisexuals. In the first review, evidence showed that mostly heterosexuals presented a particular profile of sexual and romantic behavior that differentiated them from other sexual groups. Moreover, a considerable part of the assessed samples identified themselves as mostly heterosexual and this sexual identity was subjectively meaningful (Saving-Williams \& Vrangalova, 2013). In the second review, the authors showed proof that mostly heterosexuals exhibited poorer indicators of mental and physical health than "pure" heterosexuals, however a 
slight but significant better health status than substantial bisexuals.

In a recent large web-survey, Guerin, Carvalho, and Lara (2015) examined the relationship between temperament variables and six categories of sexual orientation (heterosexuals, mostly heterosexuals, bisexuals, mostly homosexuals, and homosexuals) in sample composed of 16,571 adult participants. The authors found distinct temperament profiles related to each category of sexual orientation. Also, the authors showed that all sexual minorities (nonheterosexuals) and heterosexual with homoerotic experiences showed a less adaptive temperament profile in comparison to heterosexuals with no history of homoerotic attraction or behavior.

If congregated, the aforementioned evidence support the idea that classification of sexual orientation identities should include more than the classical three categories of heterosexual, bisexual, and homosexual. Furthermore, sexual orientation identities do not reflect ones sexual and affectional tendencies.

Moreover, when it comes to sexuality research, the methodology has a particular relevance. One of the recent advances in research of sensitive or delicate issues was using computer evaluations in order to preserve the identity and privacy of the individual. In this regard, Turner, Ku, Rogers, Lindberg, and Sonenstein (1998) showed that the evaluation by computer is far superior compared to collecting anonymous pen-and-paper questionnaires on sensitive issues such as sexuality. Moreover, the use of the Internet offers even greater benefits in terms of further ensuring privacy and enabling access to larger samples (Gosling, 2004; Reimers, 2007). Using this approach, the British Broadcasting Corporation (BBC) group conducted a study in 2005 with approximately 255,000 participants and showed that $90.3 \%$ described themselves as heterosexual, $4.2 \%$ as homosexual (gay or lesbian), and $5.5 \%$ as bisexual $(6.9 \%$ of women vs. $4.4 \%$ of men). Men were more likely to describe themselves as homosexual $(5.3 \%$ of men and $2.8 \%$ of women) (Reimers, 2007).

To ensuring privacy in regard to sensitive issues and assess large samples, an Internet based research system was developed to evaluate several psychological, behavioral and psychiatric aspects of the general population in Brazil (the Brazilian Internet Study on Temperament and Psychopathology BRAINSTEP; Lara et al., 2012). The main objective of this initiative was to investigate several social, behavioral and biological variables in the Brazilian general population, which included trends in sexual orientation and behavior.
The current study aimed to evaluate trends of sexual orientation identity in Brazilian across age and sex using five categories: heterosexuals, mostly heterosexuals, bisexuals, mostly homosexuals, and homosexuals. Also, the homoerotic ideation and behavior was surveyed among heterosexuals. Based on the aforementioned research, it was hypothesized that the prevalence rates of sexual orientation identities would be similar to the BBC study and higher than investigations based on traditional paper-and-pencil/ interviews methods, that younger generations would show higher rates of nonheterosexuality and that a considerable portion of heterosexual would display homoerotic ideation and behavior.

\section{Methods}

\section{Ethics}

The Institutional Review Board of Hospital São Lucas approved the protocol of this study (ethic $\mathrm{n}^{\circ}$ 24907813.10000.5336). All participants gave their electronic informed consent before entering the system, which was created to fulfill the requirements of the National Health Council of Brazil (Resolution 196/1996) and the Code of Ethics of the World Medical Association (Declaration of Helsinki). Participation was voluntary and anonymous and it could be canceled at any moment without justification. Personal data was sent via a secure and encrypted connection and was stored behind a firewall. Our system guaranteed anonymity by coding the e-mail addresses when data was stored, so that no one (even research staff) could have access to the e-mails of specific participants. The data was collected between November 2010 and July 2012.

\section{Participants and procedures}

Participation in the BRAINSTEP (Lara et al., 2012) was motivated by national TV and local newspaper broadcast and volunteers answered the survey by accessing the website www.temperamento. com.br. To ensure data reliability, questions checking for attention were inserted within the instruments and throughout the system. At the end of the system there were two specific questions on the degree of attention and sincerity while completing the questionnaires and scales. Only participants with age ranging from 14 to 60 who stated being attentive and sincere throughout the study and had correct answers in the attention validity checks were included. A more detailed description of BRAINSTEP may be accessed elsewhere (Lara et al., 2012). A detailed description of participants is available at Table 1 . 
The resulting sample with valid answers consisted of 41,873 participants, with 10,919 males $(26.1 \%)$ and $30,954(73.9 \%)$ females, with mean age of $30.9 \pm 10.2$ years. The sample was mostly Caucasian (73.2\%), Catholic $(41.8 \%)$ and with further education than high school $(78.3 \%)$. Being single, in a relationship and married were similarly distributed (24-35\%). A detailed description of the sample organized by gender is available in Table 1.

\section{Assessment of sexual orientation and behavior}

Sexual orientation was assessed with the question How do you define your sexual orientation? Participants were forced into choosing one among five categories of sexual orientation identity: Heterosexual, Mostly Heterosexual, Bisexual, Mostly Homosexual, and Homosexual. If a participant checked for Heterosexual, the question Many people have had some type of homosexual experience even being straight. Which alternative below corresponds to you? Was available with the following options: I have never had homosexual fantasies or contact, I have never had any homosexual contact, but I have fantasies about it, I have had some homosexual contact, but I have not had sex, I have had sex with someone of the same sex, and I prefer not to answer.

\section{Statistical analyses}

Descriptive statistics for sexual orientation were applied in total sample and separately for males and females. Other analyses were conducted in males and females subsets of the total sample. Continuous variables are presented as means and standard deviations. Categorical variables are shown as frequencies. Mean differences in age were calculated using one-way analysis of variance using Tukey post-hoc pairwise comparisons test. Frequency differences across ages were calculated with chi-square test. For the evaluation of homosexual ideas, contacts and behavior, we classified the heterosexual subsample into three age groups: teenagers (14 to 17 years of age), young adults (18 to 29 years of age), and adults ( 30 to 60 years of age).

\section{Results}

\section{Self-reported sexual orientation identities}

The majority of participants $(86.8 \%)$ self-declared to be heterosexuals, with a higher proportion in the female $(89.8 \%)$ than in the male sample $(78.2 \%)$. The two most prevalent minorities were homosexuals $(4.6 \%)$ and mostly heterosexual $(4.1 \%)$, while bisexuals were the least prevalent minority $(1.2 \%)$.

TABLE 1

Sociodemographic characteristics of the sample

\begin{tabular}{|c|c|c|c|c|}
\hline & & $\begin{array}{c}\text { Men } \\
10,919(26.1 \%)\end{array}$ & $\begin{array}{c}\text { Women } \\
30,954(73.9 \%)\end{array}$ & $\begin{array}{c}\text { Total } \\
41,873(100 \%)\end{array}$ \\
\hline Age & Mean (SD) & $31.16(10.30)$ & $30.86(10.12)$ & $30.94(10.17)$ \\
\hline Sexual Orientation & $\begin{array}{l}\text { Heterosexual } \\
\text { Mostly Heterosexual } \\
\text { Bisexual } \\
\text { Mostly Homosexuals } \\
\text { Homosexual } \\
\text { No response }\end{array}$ & $\begin{array}{c}8,537(78.2 \%) \\
393(3.6 \%) \\
156(1.4 \%) \\
382(3.5 \%) \\
1259(11.5 \%) \\
191(1.7 \%)\end{array}$ & $\begin{array}{c}27,810(89.8 \%) \\
1,314(4.2 \%) \\
346(1.1 \%) \\
405(1.3 \%) \\
665(2.1 \%) \\
412(1.3 \%)\end{array}$ & $\begin{array}{c}36,350(86.8 \%) \\
1,707(4.1 \%) \\
502(1.2 \%) \\
787(1.9 \%) \\
1924(4.6 \%) \\
603(1.4 \%)\end{array}$ \\
\hline Ethnicity & $\begin{array}{l}\text { Caucasian } \\
\text { African-American } \\
\text { Asian } \\
\text { Other }\end{array}$ & $\begin{array}{c}7,990(73.2 \%) \\
2,085(19.1 \%) \\
181(1.7 \%) \\
181(1.7 \%)\end{array}$ & $\begin{array}{c}22,768(73.6 \%) \\
5,807(18.8 \%) \\
487(1.6 \%) \\
471(1.5 \%)\end{array}$ & $\begin{array}{c}30,785(73.5 \%) \\
7,892(18.8 \%) \\
668(1.6 \%) \\
652(1.6 \%)\end{array}$ \\
\hline Education & $\begin{array}{l}\text { Basic school or less } \\
\text { High School degree } \\
\text { Incomplete University } \\
\text { University } \\
\text { Post-Graduation degree }\end{array}$ & $\begin{array}{c}188(1.7 \%) \\
2,198(20.1 \%) \\
3,617(33.1 \%) \\
2,990(27.4 \%) \\
1,926(17.6 \%)\end{array}$ & $\begin{array}{c}515(1.6 \%) \\
180(20.0 \%) \\
9,213(29.8 \%) \\
9,050(29.2 \%) \\
5996(19.4 \%)\end{array}$ & $\begin{array}{c}703(1.7 \%) \\
8,378(20 \%) \\
12,830(30,6 \%) \\
12,040(28.8 \%) \\
7922(18.9 \%)\end{array}$ \\
\hline Civil Status & $\begin{array}{l}\text { Single } \\
\text { In a relationship } \\
\text { Married } \\
\text { Divorced } \\
\text { Divorced and in a relationship } \\
\text { Widowed } \\
\text { Other }\end{array}$ & $\begin{array}{c}3804(34.8 \%) \\
2630(24.1 \%) \\
3739(34.2 \%) \\
341(3.1 \%) \\
324(3.0 \%) \\
19(0.2 \%) \\
62(0.6 \%)\end{array}$ & $\begin{array}{c}9385(30.3 \%) \\
7687(24.8 \%) \\
11012(35.6 \%) \\
1607(5.2 \%) \\
812(2.6 \%) \\
231(0.7 \%) \\
220(0.7 \%)\end{array}$ & $\begin{array}{c}13189(31.5 \%) \\
10317(24.6 \%) \\
14751(35.2 \%) \\
1948(4.7 \%) \\
1136(2.7 \%) \\
250(0.6 \%) \\
282(0.7 \%)\end{array}$ \\
\hline Religion & $\begin{array}{l}\text { Catholic } \\
\text { Jewish } \\
\text { Protestant } \\
\text { Kardecist } \\
\text { Other } \\
\text { No religion }\end{array}$ & $\begin{array}{c}4117(37.7 \%) \\
44(0.4 \%) \\
1400(12.8 \%) \\
1211(11.1 \%) \\
771(7.1 \%) \\
3376(30.9 \%)\end{array}$ & $\begin{array}{c}13378(43.2 \%) \\
107(0.3 \%) \\
4900(15.8 \%) \\
4809(15.5 \%) \\
1898(6.1 \%) \\
5862(18.9 \%)\end{array}$ & $\begin{array}{c}17495(41.8 \%) \\
151(0.4 \%) \\
6300(15 \%) \\
6020(14.4 \%) \\
2669(6.4 \%) \\
9238(22.1 \%)\end{array}$ \\
\hline
\end{tabular}


There were $11.3 \%$ and $3.5 \%$ males who self-declared homosexual and mostly homosexuals, respectively, compared to $2.1 \%$ and $1.3 \%$ among females. Also, a minority of participants preferred not to respond this question (1.4\%). Table 1 details the sexual orientation and demographic variables for the total sample and for the male and female subsets of the sample.

\section{Age related differences in the distribution of sexual orientation}

As shown in Figure 1, there were significant age differences between the sexual orientation groups for the male sample: bisexuals $(M=26.1 \pm 10.2)$, mostly homosexuals $(\mathrm{M}=26.3 \pm 9.2)$, and homosexuals $(\mathrm{M}=28.3 \pm 8.6)$ were significantly younger $(p<0.001)$ than mostly heterosexuals $(\mathrm{M}=30.7 \pm 11.1)$ and heterosexuals $(M=30.5 \pm 10.4)$. In the female sample, bisexuals $(M=25.5 \pm 8.8)$ were the youngest group and statistically different from all others. Mostly homosexuals $(\mathrm{M}=27.9 \pm 10.4)$ and mostly heterosexuals $(\mathrm{M}=28.0 \pm 9.6)$ were younger than homosexuals $(M=29.0 \pm 9.4)$ and heterosexuals $(M=29.8 \pm 10.2)$. These results were further explored in Figure 2 for each sexual orientation group.

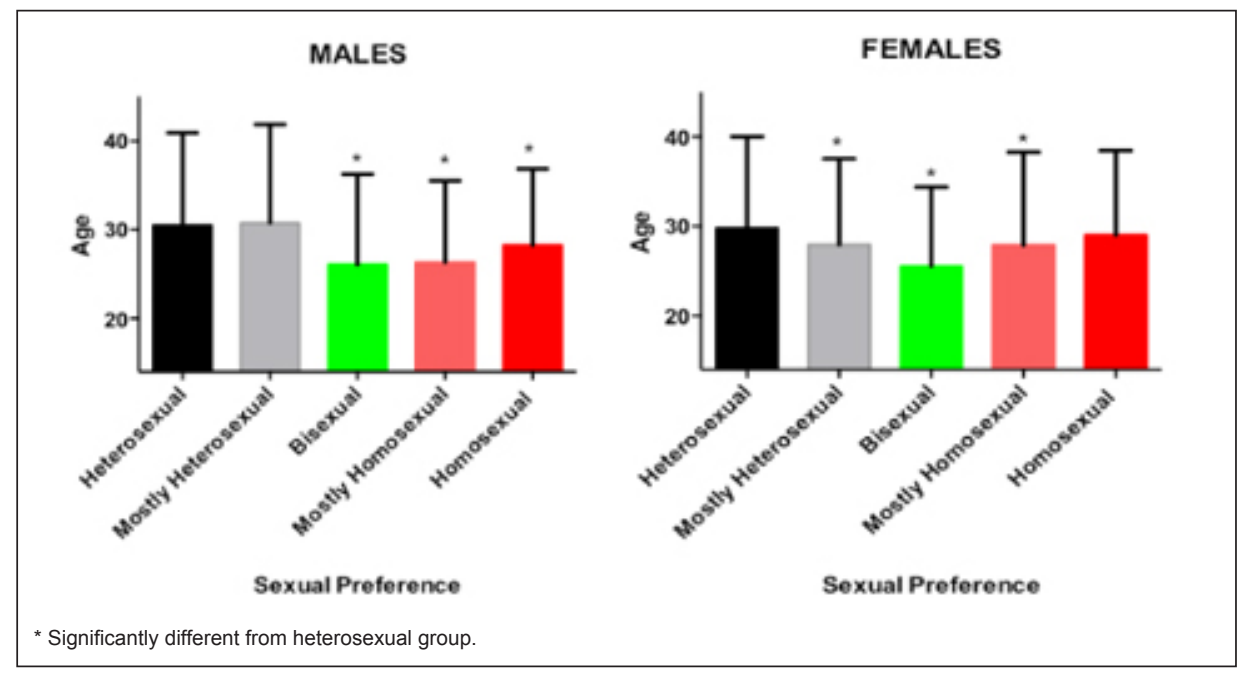

Figure 1. Age differences between sexual orientation groups. Data was analyzed with ANOVA followed by Tukey's post hoc.

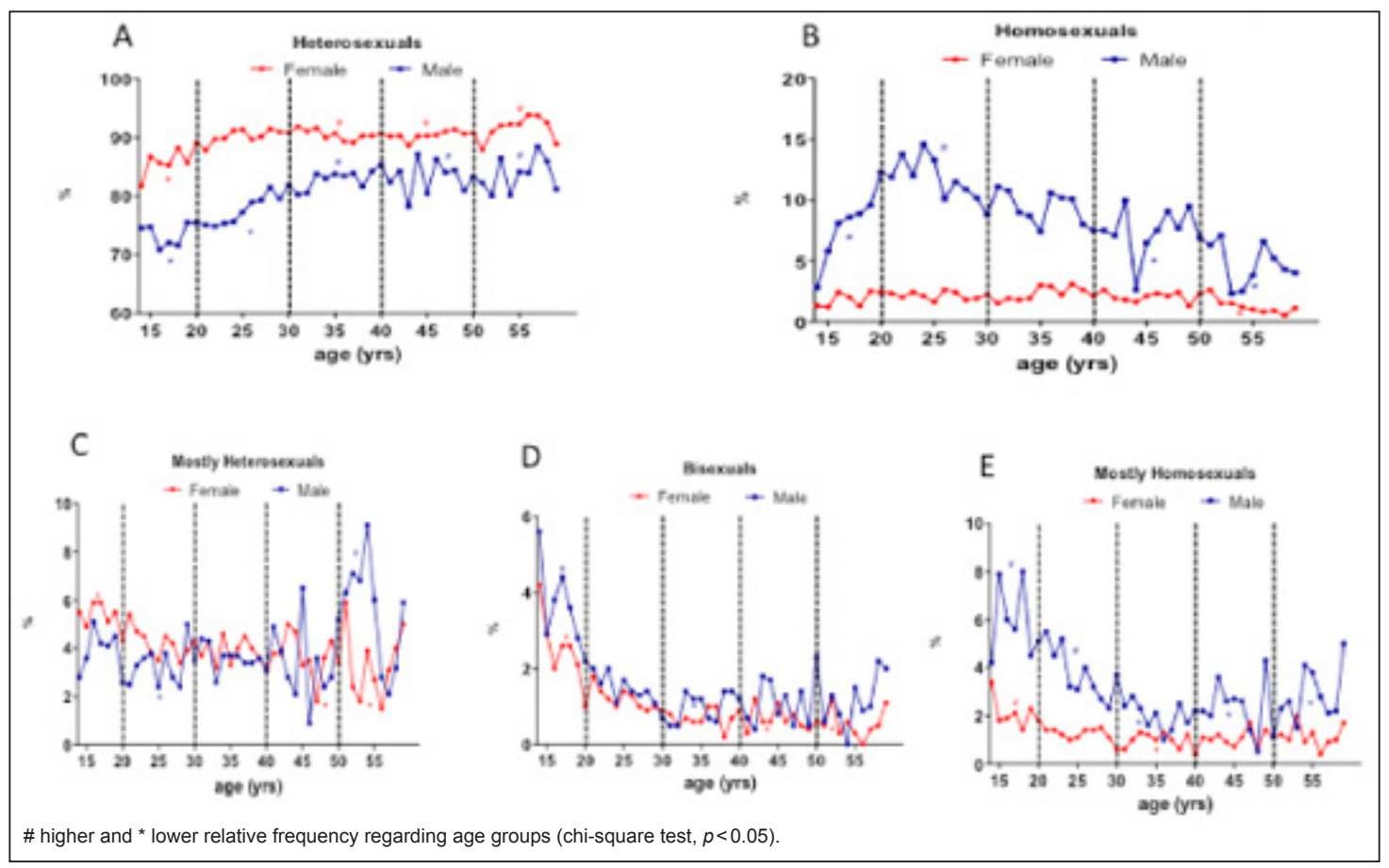

Figure 2. Relative frequencies of sexual orientations according to age. Percentage of males and females are show heterosexuals (A), homosexuals (B), bisexuals with preference for other sex (C), no preference (D) and for the same sex $(\mathrm{E})$. 


\section{Heterosexuals (Figure 2A)}

Among males, there were a significantly lower proportion of self-declared heterosexuals between 14 and 30 years of age and a higher frequency between 30 and 60 years of age. Among females, there were fewer heterosexuals between 14 and 20 years of age.

\section{Homosexuals (Figure 2B)}

Among males, there was a lower proportion of this group between 14 and 20 years of age and between 40 and 60 years but a higher frequency between 20 and 30 years. Females showed only a decrease between the ages of 50 and 60 years.

\section{Mostly heterosexuals (Figure 2C)}

Among males, there was lower proportion of this group between 20 and 30 years and a higher proportion between 50 and 60 years. Females showed a higher proportion between 14 and 20 years and a lower proportion between 40 and 60 years.

\section{Bisexuals (Figure 2D)}

More males reported to be bisexual with no preference more often between 14 and 20 years of age, with a lower frequency between 40 and 60 years. In females there was a higher proportion between 14 and 20 years of age and a lower frequency between 30 and 40 years.

\section{Mostly homosexuals (Figure 2E)}

Males between 14 and 30 years of age more often reported this sexual orientation whereas between 30 and 60 years the frequency was lower. Females showed a higher proportion between 14 and 20 years of age and a lower frequency between 30 and 40 years of age.

\section{Homoerotic thoughts and behaviors among heterosexuals}

Among males, heterosexuals who declared to have had sex with someone of the same sex were significantly older $(\mathrm{M}=35.9 \pm 10.97, p<0.001)$ than other groups (Figure 3A). In the female sample, heterosexuals who had contact, but not sex, were significantly younger than others $(\mathrm{M}=28.3 \pm 9.1, p<0.001)$ and the ones who had sex were significantly older $(\mathrm{M}=33.1 \pm 9.8$, $p<.001$ ) (Figure 3B).

Accordingly, the relative frequencies of homoerotic ideas, contact and sex between age groups were different among male $\left(\chi^{2}=250.875, \mathrm{df}=8, p<0.001\right)$ and female heterosexuals $\left(\chi^{2}=381.583, \mathrm{df}=8\right.$, $p<0.001)$. In heterosexual males, there was an age related increase of homoerotic behavior and decrease of thinking/fantasizing of homosexual behavior, with little change in homoserotic ideas and contacts. Among male teenagers, 3.4\% reported sex with other man compared to $7.2 \%$ and $15.8 \%$ of $18-29$ and $>30$ years groups, respectively (Figure $3 \mathrm{C}$ ). Also, there was an age

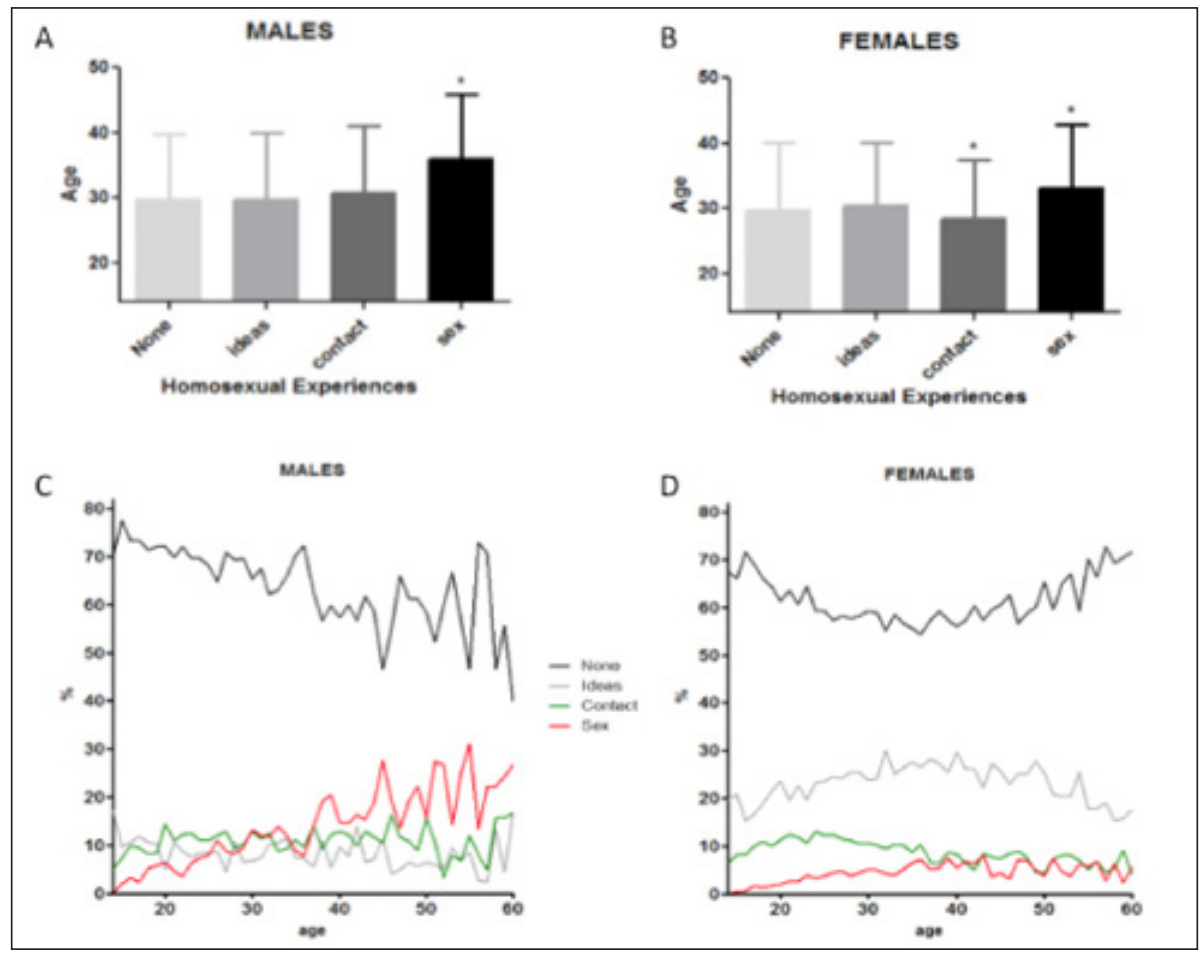

Figure 3. Age of heterosexuals with homosexual ideas, contact and sex. Age means and distribution are shown respectively for males (A and C) and females (B and D). 
related decrease in the frequency of male heterosexuals without homosexual fantasies or behavior, declining from around $70 \%$ in early twenties to $55 \%$ in the fifties. Among heterosexual females, homoerotic ideas and sex increased with age, whereas contact had its peak at the 18-29 years age group. Sex with another woman was reported by $0.9 \%$ female teenagers compared to $3.2 \%$ and $5.3 \%$ of $18-29$ and $>30$ years groups, respectively (Figure 3D).

\section{Discussion}

The current investigation aimed at exploring trends in sexual orientation identity in Brazil across age and sex. Also, homoerotic ideation and homosexual behavior were surveyed among participants who declared to be heterosexuals. The most prevalent minorities were homosexuals $(4.6 \%)$ and mostly heterosexuals (4.1\%): men declared to be homosexual more often than women ( $11.5 \%$ versus $2.1 \%)$, while women declared to be mostly heterosexual more often than men $(4.2 \%$ versus $3.6 \%)$. In the male sample, nonheterosexuality was clearly more prevalent among adolescents and young adults. Among females, bisexuality was more frequent among adolescents. Our data suggests that sexuality of men is more distributed among the assessed categories than that of women and that non-heterosexuality is more recurrent in younger generations.

Our results showed that higher rates of nonheterosexuality in youth were paralleled by higher prevalence of mostly heterosexuals among men in their 50's, and lower rates in older generations of heterosexual men without homoerotic/sexual ideation and contact. Taken together, this data may suggest that people from younger generations may recognize and express their homosexual tendencies more often than older generations.

Compared to other studies, our results showed that homosexuality $(4.6 \%)$ and bisexuality $(7.2 \%)$ were more frequent and the prevalence of homosexuality among men was particularly high (11.5\%). The previous Brazilian population study by Abdo (2004) reported those $2.4 \%$ and $6.1 \%$ self-declared homosexuals and $0.9 \%$ e $1.8 \%$ self-declared bisexuals, respectively for women and men, using anonymous pen-and-paper questionnaires. In New Zealand the frequency of homosexuality and bisexuality was $0.8 \%$ and $0.6 \%$, respectively, but the method of data collection was face-to-face interview (Wells, McGuee, \& Beautrais, 2011). Using a telephone anonymous interview conducted in Massachusetts between 2001 and 2008, Conron, Mimiaga, \& Landers (2010) found that $3 \%$ of the sample identified themselves as either gay or lesbian $(2.0 \%)$ or bisexual $(1.0 \%)$, with bisexuals being significantly younger. In Canada and the USA, the proportion of homosexuals and bisexuals combined was 3\% among men and 2\% among women in a sample of college students using self-administered questionnaires (Ellis, Robb, \& Burke, 2005). They also reported that roughly $10 \%$ of both sexes have at least half of their sexual fantasies involving same-sex partners. Also, about $5 \%$ of nonvirgin males and $0.5 \%$ of non-virgin females declared that all of their experiences had involved samesex partners. In Australia using computer-assisted telephone interviews, the rate of homosexuality was $1.6 \%$ for males and $1.4 \%$ for females, and bisexual orientation was reported by $0.9 \%$ of males e $1.4 \%$ of women (Smith, Rissel, Richters, Grulich, \& Visser, 2003), but some same-sex attraction or experience was reported by $8.6 \%$ of men and $15.1 \%$ of women. Using a web-based method, the BBC study conducted in 2005 in over 200.000 individuals observed 5.8\% homosexuality and $4.6 \%$ bisexuality in men and $2.8 \%$ and $6.9 \%$ in women, respectively, with self-declared bisexual females also being significantly younger (Reimers, 2007). More recently, using anonymous pen-and-paper self-administered questionnaires in adolescents, Pathela and Schillinger (2010) reported that $3.2 \%$ of sexually active male and females had only same-sex behavior, but fewer male than female adolescents reported both-sex partners $(3.7 \%$ vs $8.7 \%)$. Interestingly, many sexually active adolescents with same- or both-sex partners identified themselves as heterosexual/straight $(39.4 \%$ of male and $38.7 \%$ of female adolescents). These findings suggested a high mismatch between sexual identity and sexual behavior in this age group. Thus, our study showed higher rates of homosexuality in men and relatively high rates of intermediate categories (bisexuals and mostly hetero/ homosexuals) in men and women, but our rates were more comparable to studies that used similar webbased anonymous methodologies or that focused on on younger generations.

The evidence portrayed in the current paper also shows that sexual identity and sexual behavior/ attraction are related, however not a perfectly overlapping phenomena. In fact, our data indicates that an important amount of substantial heterosexuals, particularly among men, engage in homosexual acts and display homoerotic fantasies. Therefore, research that aims to understand sexuality should approach it by examining various concepts simultaneously, such as: sexual identity, ideation, behavior, attraction, etc. In fact, neuroimaging findings show that the experience 
of love (affection) and desire (sexual) may or may not display similar neurobiological underpinnings: brain activation patterns in determined regions such as the caudate, putamen, insula, and anterior cingulate cortex are active in both love and desire. On the other hand, ventral tegmental area seems to be specifically active during desire and sexual arousal experiences (Diamond \& Dickenson, 2012). These findings raise the possibility that certain types of love and desire may be relatively distinct from one another whereas others are more interconnected. This multiplicity of experiences (sexual desire without love, love without sexual desire and love with sexual desire) may influence the way people develop their sexual identity.

Similarly to Saving-Williams and Vrangalova, (2013; 2014) proposals, data presented in this study also displayed proof of the validity of the intermediate categories of mostly homosexual and mostly heterosexual: first, a considerable part of the assessed sample identified themselves in these categories, showing an important prevalence rate and, second, sex and age variations in these groups produced interpretable and heuristic results.

We also observed a generational shift: Our findings are in accordance with Ott, Corliss, Wypij, Rosario, and Autin (2011) that reported an increase of "completely homosexual" compared to "mostly homosexual" and "bisexual" between 15 and 23 years of age in males only. They also found that age was positively associated with endorsing a sexual-minority orientation identity, which in our study was only observed for males endorsing homosexuality. Likewise, our results showed that age was inversely associated with endorsing bisexuality, which is in accordance with other studies that showed that younger generations, in particular women, tend to self-declare more often as bisexual.

The reasons for the higher prevalence of nonheterosexual orientation in younger generations are not clear. There are many theories about the determination of sexual orientation, but increasing evidence suggests that it is determined by a conjuncture of factors, such as genetic (Burri, Cherkas, Spectos, \& Rahman, 2011; Hamer, Hu, Magnuson, Hu, \& Pattatucci, 1993; Whitam \& Matrhy, 1991), neurobiological (Rahman, 2005; Diamond \& Dickenson, 2012; Burke, Manzouri, Dhejne, Bergstrom, Arver, Fausner, \& Savic-Berglung, in press), hormonal (Balthazart, 2011; Leinung \& Wu, in press), cultural (Green, 2000; Kulic, 2009) and psychological, such as Bem's (1996) theory on how child's preferences on sex-typical or sex-atypical activities and peers may influence sexual orientation in adulthood. Such rapid changes are unlikely to have a genetic basis and suggest psychological and cultural modifications in the person-environment relationship, although biological factors cannot be completely excluded.

Methodological differences in data collection of sensitive issues may have a large impact in the observed rates due to the level of privacy offered by the method. Turner et al. (1998) has shown that homosexual acts (performing oral sex or receptive anal sex) are 5 to 7 times more frequently declared in a computer-assisted self-interviewing interface compared to traditional anonymous pen-and-paper method. When the respondents answer on a paper form with their identification number, some of them may become suspicious about the privacy of their information. Anonymous telephone interviews also have this problem, since the telephone number is identified, and face-to-face interviews are the least adequate. In our methodology, accuracy is putatively enhanced by using an anonymous computer interface at a distance (i.e. no contact at all with researchers), by voluntary enrollment and by providing a feedback on the volunteer's temperament profile. However, the major incentive for participation is self-knowledge and involves answering questionnaires and scales, biasing the sample towards more women. It is also possible that enrolling in our study may be relatively more appealing to males with bisexual or homosexual orientation, therefore inflating this absolute numbers. On the other hand, it is difficult to conceive that this selection bias would apply to younger but not older (e.g. $>30$ years) males, suggesting that at least the relative increase in non-heterosexual orientations is valid. Another limitation of our study is the selection of a population that has access to Internet, therefore over-representing the more educated and richer part of the population.

In conclusion, we observed an increase in nonheterosexual orientation in the younger generations, particularly of homosexuality and bisexuality with same sex preference in males and bisexuality with preference for the other sex or no preference in females. Further studies with methodologies preserving privacy (preferentially with computer interface) and with a population-based sample are necessary to corroborate these findings. 


\section{References}

Abdo, C. H. N. (2004). Descobrimento sexual do Brasil: para curiosos e estudiosos. São Paulo: Summus.

Abdo, C. H. N. (2010). Sexualidade Humana e seus transtornos (3 $3^{\text {rd }}$ ed). São Paulo: Leitura Médica.

Balthazart J. (2011). Minireview: Hormones and human sexual orientation. Endocrinology, 152(8), 2937-2947. https:// doi.org/10.1210/en.2011-0277

Bem, D. (1996). Exotic becomes erotic: A developmental theory of sexual orientation. Psychological Review, 103, 320-335. https://doi.org/10.1037/0033-295X.103.2.320

Black, D., Gates, G., Sanders, S., \& Taylor, L. (2000). Demographics of gay and lesbian population in the United States: Evidence from available systematic data source. Demography, 37(2), 139-154. https://doi.org/10.2307/2648117

Burke, S. M., Mazouri, A. H., Dhejne, C., Bergstrom, K., Arver, S., Feusner, J. D., \& Savic-Berglund. (in press). Testosterone effects on the Brain in transgender men. Cerebral Cortex. https://doi.org/10.1093/cercor/bhx054

Burri A., Cherkas, L., Spector, T., \& Rahman, Q. (2011). Genetic and environmental influences on female sexual orientation, childhood gender typicality and adult gender identity. PLoS One, 6, e21982. https://doi.org/10.1371/ journal.pone.0021982

Conron KJ, Mimiaga MJ, Landers SJ. (2010). A population-based study of sexual orientation identity and gender differences in adult health. American Journal of Public Health, 100(10), 1953-1960. https://doi.org/10.2105/ AJPH.2009.174169

Diamond, L. M. (2003). What does sexual orientation orient? A biobehavioral model distinguishing romantic love and sexual desire. Psychological Review, 110, 173-192. https://doi.org/10.1037/0033-295X.110.1.173

Diamond, L. M., \& Dickenson, J. A. (2012). The neuroimaging of love and desire: review and future directions. Clinical Neuropsychiatry, 9(1), 39-46

Ellis, L., Robb, B., \& Burke, D. (2005). Sexual Orientation in United States and Canadian College Students. Archives of Sexual Behavior, 34(5), 569-581. https://doi.org/10.1007/s10508-005-6283-8

Gosling, S. D., Varize, S., Srivastava, S. \& John, O. P. (2004). Should We Trust Web-Based Studies? A comparative analysis of six preconceptions about Internet questionnaires. American Pshycologist, 59(2), 93-104. https://doi. org/10.1037/0003-066X.59.2.93

Green, J. (2000). Além do Carvaval: A Homossexualidade Masculina no Brasil do Século XX. São Paulo: Editora Unesp.

Guerin, L. D., de Carvalho, H. W., \& Lara, D. R. (2015). The relationship between temperament and sexual orientation. Journal of Affective Disorders, 175, 379-384. https://doi.org/10.1016/j.jad.2015.01.029

Hamer, D. H., Hu, S., Magnuson, V. L., Hu, N., \& Pattatucci, A. M. L. (1993). A linkage between DNA markers on the $\mathrm{X}$ chromosome and male sexual orientation. Science, 261, 321-327. https://doi.org/10.1126/science.8332896

Kaplan, H. \& Sadock, B. J. (1984). Compêndio de Psiquiatria Dinâmica. Porto Alegre: Artmed.

Kinsey, A. C., Pomeroy, W. B., \& Martin, C. R. (1948). Sexual behavior in human male. Philadelphia: WB Saunders.

Kinsey, A., Pomeroy, W., Martin, C., \& Gebhard, P. (1953). Sexual behavior in the human female. Philadelphia: WB Sauders.

Lara, D. R., Ottoni, G. L., Brunstein, M. G., Frozi, J., de Carvalho, H. W., \& Bisol, L. W. (2012). Development and validity data of the Brazilian Internet Study on temperamento and Psychopathology (BRAINSTEP). Journal of Affective Disorders, 141, 390-398. https://doi.org/10.1016/j.jad.2012.03.011

Leinung, M., Wu, C. (in press). The biological basis of transgender identity: 2D:4D Finger length ratios implicate a role for prenatal androgen acticity. Endocrinal Practice. https://doi.org/10.4158/EP161528

Maslow, A. H. \& Sakoda, J. M. (1952). Volunteer-error in the Kinsey study. Journal of Abnormal Psychology, 47(2), 259-262. https://doi.org/10.1037/h0054411

McCabe, J., Brewster, K. L. \& Tillman, K. H. (2011). Patterns and Correlates of Same-Sex Sexual Activity Among U.S. Teenagers and Young Adults. Perspectives on Sexual and Reproductive Health, 43, 142-150. https://doi. org $/ 10.1363 / 4314211$

Ott, M. Q., Corliss, H. L., Wypij, D., Rosario, M., \& Austin, S. B. (2011). Stability and Change in self-reported Sexual Orientation Identity in Young People: Aplication of Mobility Metrics. Archives of Sexual Behavior, 40(3), $519-532$. https://doi.org/10.1007/s10508-010-9691-3

Pathela, P. \& Schillinger, J. A. (2010). Sexual Behaviors and Sexual Violence: Adolescents With Other-, Same-, or BothSex Partners. Pediatrics, 126(5), 879-886. https://doi.org/10.1542/peds.2010-0396

Rahman, Q. (2005). The neurodevelopment of human sexual orientation. Neuroscience and Biobehavioral Reviews, 29,1057-1066. https://doi.org/10.1016/j.neubiorev.2005.03.002

Reimers S. (2007). The BBC Internet Study: General Methodology. Archives of Sexual Behavior, 36, 147-161. https:/ doi.org/10.1007/s10508-006-9143-2

Saving-Williams, R. C. \& Ream, G. L. (2007). Prevalence and stability of sexual orientation components during adolescence and young adulthood. Archives of Sexual Behavior, 36(3), 385-394. https://doi.org/10.1007/s10508-0069088-5 
Saving-Williams, R. C. \& Vrangalova, Z. (2013). Mostly heterosexuals as a distinct sexual orientation group: A systematic review of the empirical evidence. 2013. Developmental Review, 33(1), 58-88. https://doi.org/10.1016/j.dr.2013.01.001

Saving-Williams, R. C. \& Vrangalova Z. (2014). Psychological and physical health of mostly heterosexuals: a systematic review. The Journal of Sex Research, 51(4), 410-445. https://doi.org/10.1080/00224499.2014.883589

Sell, R. L., Wells, J. A., \& Wypij, D. (1995). The Prevalence of Homosexual Behavior and Attraction in the United States, the United Kingdom and France: Results of National Population-Based Samples. Archives of Sexual Behavior, 24(3), 235-248. https://doi.org/10.1007/BF01541598

Smith, A. M. A., Rissel, C. E., Richters, J., Grulich, A. E., \& Visser, R. O. (2003). Sex in Australia: Sexual identity, sexual attraction and sexual experience among a representative sample of adults. Australian and New Zealand Journal of Public Health, 27, 138-145. https://doi.org/10.1111/j.1467-842X.2003.tb00801.x

Turner, C. F., Ku, L., Rogers, S. M., Lindberg, L. D., Pleck, J. H., \& Sonenstein, F. L. (1998). Adolescent Sexual Behavior, Drug Use, and Violence: Increased Reporting with Computer Survey Technology. Science, 280, 867-873. https://doi. org/10.1126/science.280.5365.867

Voeller, B. (1990). Some uses and abuses of the Kinsey Scale. In McWhirter, D. P., Sanders, S. A., \& Reinisch, J. M. (eds.). Homosexuality/Heterosexuality: Concepts of Sexual Orientation. New York, NY: Oxford University Press.

Wells, J. E., McGee, M. A., \& Beautrais, A. L. (2011). Multiple Aspects of Sexual Orientation: Prevalence and Sociodemographic Correlates in a New Zealand National Survey. Archives of Sexual Behavior, 40(1), 155-168. https://doi.org/10.1007/s10508-010-9636-x

Whitam, F. L. \& Matrhy, R. M. (1991). Childhood cross-gender behavior of homosexual females in Brazil, Peru, the Philippines and the United States. Archives of Sexual Behavior, 20(2), 151-170. https://doi.org/10.1007/BF 01541941

\author{
Autores: \\ Hudson W. de Carvalho - Doutor, Universidade Federal de Pelotas. \\ Simone Conte Dall'Ágnol - Especialista, Pontifícia Universidade Católica do Rio Grande do Sul. \\ Diogo Rizzato Lara - Doutorado, Pontifícia Universidade Católica do Rio Grande do Sul. \\ Endereço para correspondência: \\ Hudson W. de Carvalho \\ Av. Duque de Caxias, 250 - Fragata \\ 96030-001, Pelotas, RS, Brasil \\ Recebido em: 12.02 .2017 \\ Aceito em: 27.03.2017
}

